\title{
PEMBANGUNAN KEPIMPINAN WANITA: MEMBINA ILMU WATAN BAGI KEPIMPINAN WANITA MENERUSI KEHIDUPAN TUN FATIMAH HASHIM
}

\section{THE DEVELOPMENT OF WOMEN'S LEADERSHIP: CONSTRUCTING LOCAL KNOWLEDGE ON WOMEN'S LEADERSHIP THROUGH THE LIFE OF TUN FATIMAH HASHIM}

\author{
Muhammad Rahimi Hasan" dan Bahiyah Abdul Hamid \\ Pusat Kepimpinan Wanita Tun Fatimah Hashim, Universiti Kebangsaan \\ Malaysia, MALAYSIA \\ *Corresponding author: muhdrahimihasan@gmail.com \\ Published online: 15 April 2017 \\ To cite this article: Muhammad Rahimi Hasan and Bahiyah Abdul Hamid. 2017. Pembangunan \\ kepimpinan wanita: membina ilmu watan bagi kepimpinan wanita menerusi kehidupan Tun \\ Fatimah Hashim. Kajian Malaysia 35(1): 91-116. https://doi.org/10.21315/km2017.35.1.5 \\ To link to this article: $\mathrm{https}: / /$ doi.org/10.21315/ km2017.35.1.5
}

\begin{abstract}
ABSTRAK
Kajian ini tertumpu kepada aspek teoretis kepimpinan wanita berdasarkan pengalaman pemimpin wanita Melayu, sekali gus Malaysia iaitu Tun Fatimah Hashim (1924-2010). Selama empat dekad kepimpinannya, kedudukan politik Fatimah Hashim sebagai Ketua Kaum Ibu United Malays National Organization, (UMNO) (1956-1972) meletakkan beliau di barisan hadapan kepimpinan wanita. Selanjutnya, beliau telah dilantik sebagai Menteri Kebajikan Am (19691973) yang bermaksud menteri pertama dalam kalangan wanita Malaysia. Peranan Fatimah Hashim selaku Yang Dipertua National Council of Women's Organisations (NCWO) sejak 1965 sehingga 1989 mewajarkan lagi kepimpinan Fatimah Hashim dikaji selidik. Kesignifikanan penyelidikan kepimpinan Fatimah Hashim adalah kerana kelahiran dan pembangunan kepimpinan beliau pada era pramerdeka dan awal pascamerdeka yang bercakerawalakan masyarakat konservatif-patriarki. Ketika itu, masih lagi belum termaktub secara rasmi sebarang komitmen daripada pihak kerajaan untuk melindungi dan membela hak-hak wanita seperti Dasar Wanita Negara, mahupun Convention on the Elimination of All Forms of Discrimination Against Women (CEDAW) yang diratifikasi Kerajaan Malaysia pada tahun 1995. Kewujudan budaya patriarki yang masih tebal dan ketiadaan kerangka undang-undang bersifat membela dan memperkasa hak golongan wanita secara tidak langsung mewujudkan isu kepimpinan wanita. Pertama, sebab-musabab Fatimah Hashim diangkat dijulang sebagai pemimpin wanita Malaysia meskipun berada dalam persekitaran yang
\end{abstract}


tidak mendukung pembangungan kepimpinan wanita - isu halangan wanita menjadi pemimpin masyarakat. Kedua, sebagai pemimpin wanita, Fatimah Hashim berusaha secara konsisten melawan persekitaran konservatif-patriarkal dengan mengartikulasikan tuntutan hak wanita - isu penerimaan masyarakat terhadap kepimpinan wanita. Ketiga, zaman yang serba mencabar itu mempengaruhi pencapaian perjuangan hak wanita yang dipimpin oleh Fatimah Hashim - isu keberkesanan kepimpinan wanita. Akhirnya, kajian ini menganjurkan agar penjelasan teoretis kepimpinan wanita berlandaskan ilmu watan dibangunkan. Hal ini kerana penjelasan pengalaman kepimpinan Fatimah Hashim berdasarkan penilaian teoretis para sarjana tempatan didapati lebih memuaskan berbanding penjelasan teoretis-empiris yang berpusatkan pengalaman Barat.

Kata kunci: Fatimah Hashim, kepimpinan wanita, hak wanita Malaysia, isu gaji sama untuk wanita

\begin{abstract}
This study focuses on the theoretical aspect of women's leadership based on the experience of a distinguished Malay woman leader, namely Malaysia's very own Tun Fatimah Hashim (1924-2010). Tun Fatimah Hashim's political position as the Leader of Kaum Ibu UMNO (Women's Wing of United Malays National Organization, UMNO) for the four decades of her leadership (from 1956 to 1972) has placed her at the forefront of women's leadership in Malaysia. Her appointment as the Welfare Minister in the Malaysian cabinet (1969-1973); the first minister among Malaysian women attest to her ability as a formidable leader. Her role as the Head of National Council of Women's Organisations (NCWO) from 1965 until 1989 further justifies that there should be studies carried out to investigate Tun Fatimah Hashim's leadership especially among local researchers. To understand why this study is significant, we must first understand the socio-political context that gave rise to the leadership of Fatimah Hashim, significantly that of the pre-independence and the early postindependence period within the milieu of a conservative-patriarchal society. At that time, there was no officially-written commitment from the government to protect and defend women's rights such as the National Women's Policy or the Convention on the Elimination of All Forms of Discrimination Against Women (CEDAW) ratified by the Malaysian Government in 1995. The resilience existence of a strong patriarchical culture and the non-existence of legislative framework to defend and strengthen the rights of women have indirectly sparked interest on the issues of women leadership. Firstly, one of the reasons which has elevated Fatimah Hashim as a woman leader in Malaysia is her capability to centralise the issue of women's obstacles in becoming community leaders despite
\end{abstract}


living in an environment which was indifferent to women's development. Secondly, as a woman leader, Fatimah Hashim strived consistently to fight the conservative-patriarchal environment by articulating women's rights - the issue of claiming women's rights through the public's acceptance of women's leadership. Thirdly, the influence of living in challenging times and its effects on the struggle for women's rights led by Fatimah Hashim - the issue of the effectiveness of women's leadership. Lastly, it is hoped that this study will develop public knowledge on women's leadership based on local knowledge specifically through theoretical assessment by local researchers and scholars on Fatimah Hashim's leadership. We feel that this kind of endeavour will be more effective compared to the empirical theoretical explanation which centres on the experience of the West.

Keywords: Fatimah Hashim, women's leadership, Malaysian women's rights, issue of equal pay for women

\section{PENGENALAN}

Mengapakah isu kepimpinan Tun Fatimah Hashim wajar sekali diberi perhatian khusus? Istimewanya sosok Fatimah Hashim dalam dunia kepimpinan wanita Malaysia kerana kedudukan beliau sebagai pemimpin tertinggi untuk tempoh yang panjang iaitu Ketua Kaum Ibu United Malays National Organization (UMNO) selama 16 tahun dan Yang Dipertua National Council of Women's Organisations (NCWO) selama 24 tahun. Menerajui organisasi wanita semenjak tahun 1956 hingga 1989, tempoh lama sebegini memberi peluang kepada Fatimah Hashim untuk melakukan sesuatu demi memartabatkan hak wanita Malaysia. Bagi menggambarkan betapa ulungnya Fatimah Hashim dalam dunia kepimpinan, baik semasa menjadi anggota kerajaan, mahupun ahli badan bukan kerajaan, Fatimah Hashim telah menempuh era kepimpinan empat Perdana Menteri Malaysia iaitu Tunku Abdul Rahman Putra al-Haj (1955-1969), Tun Abdul Razak Hussein (1970-1978), Tun Hussein Onn (1979-1982) dan Tun Dr. Mahathir Mohamad (1983-2002). Di sebalik setiap peralihan tampuk kepimpinan negara, Fatimah Hashim berterusan memastikan agenda wanita tidak terpinggir daripada arus pembangunan.

Bagi meneroka dan mengupas isu pembangunan kepimpinan Fatimah Hashim, beberapa objektif digariskan yang mana setiap satunya berkesinambungan antara satu sama lain. Pertamanya, meninjau sepintas lalu perbahasan teori kepimpinan oleh para sarjana daripada luar dan lebih-lebih lagi oleh sarjana tempatan, khususnya konteks kepimpinan wanita Melayu. Oleh sebab teori kepimpinan adalah luas cakupan perbincangannya, maka kajian ini hanya tertumpu kepada konteks kepimpinan Fatimah Hashim. Keduanya, setelah meninjau teori kepimpinan, kajian ini meneliti faktor-faktor yang mempengaruhi 
pembangunan kepimpinan Fatimah Hashim. Ketiga, dengan tumpuan terhadap isu hak gaji sama rata untuk wanita, kajian ini menghubung kait pengaruh kepimpinan Fatimah Hashim terhadap keberkesanan perjuangan hak wanita Malaysia.

\section{Fatimah Hashim: Lakaran Kehidupan Srikandi Negara}

Sebagai tokoh pemimpin wanita, nama Fatimah Hashim sememangnya telah pun dikenali. Akan tetapi, lembaran kehidupan peribadi beliau yang berkait rapat dengan sosialisasi kepimpinan adakalanya masih menjadi "rahsia" buat segelintir masyarakat yang lahir di luar era kepimpinannya.

Fatimah Hashim dilahirkan pada 25 Disember 1924, di Kampung Parit Keroma, Muar, Johor. Beliau merupakan anak ketiga dalam keluarga besar seramai 24 orang adik-beradik sebapa tetapi berlainan ibu. Suatu yang tidak asing dalam masyarakat Melayu waktu itu, Fatimah Hashim dibesarkan oleh ibu saudaranya yang tidak mempunyai anak kandung. Sebagai anak angkat, Fatimah Hashim diasuh oleh keluarga yang memiliki pegangan agama yang kuat kerana bapa saudara beliau berjawatan bilal masjid. Pendidikan awal Fatimah Hashim diperoleh dengan menumpang di sekolah vernakular Melayu, Sekolah Melayu Lelaki Kampung Parit Keroma kerana ketiadaan sekolah untuk kanak-kanak perempuan di kampung tersebut. Namun, Fatimah Hashim kembali kepada keluarga asal kerana ibu saudaranya meninggal dunia ketika beliau menginjak usia 13 tahun, lalu berpindah ke Sekolah Perempuan Mersing. Walau bagaimanapun, pendidikan Fatimah Hashim secara formal telah terganggu akibat Perang Dunia Kedua. Latihan perguruan yang beliau jalani berakhir begitu sahaja (Azizah, 1990: 25-26; Nik Safiah dan Rokiah, 2003: 1-2).

Dekad 1930-an menyaksikan gelombang kesedaran pendidikan wanita Melayu. Keprihatinan kelompok intelektual Melayu terhadap agenda pendidikan formal wanita Melayu mendorong penambahbaikan dasar kolonial British dalam bidang pendidikan. Perubahan sikap ibu bapa yang tidak mengambil berat kepentingan pendidikan untuk anak-anak perempuan juga berlaku di sebalik krisis kecemburuan sosial masyarakat Melayu terhadap bangsa asing. Hal ini kerana penempatan di kawasan bandar membolehkan bangsa asing menikmati faedah daripada kepesatan kegiatan ekonomi kapitalisme dan kemudahan pendidikan iaitu sekolah-sekolah yang dibina di bandar-bandar (Mahani, 2010). Tanggungjawab memajukan pendidikan formal wanita Melayu digalas oleh segolongan guru wanita Melayu dari Johor, terutamanya Ibu Zain. Pusat kegiatan guru-guru Melayu Johor ini bertapak di negeri kelahiran Fatimah Hashim. Bapa beliau, Cikgu Hashim, ialah pendidik berpengalaman yang bertugas sebagai nazir sekolah di daerah Mersing, Johor. Oleh yang demikian, dalam aspek latar pendidikan, Fatimah Hashim begitu beruntung kerana menikmati pendidikan formal yang lebih baik berbanding kanak-kanak perempuan Melayu lain waktu itu. 
Melangkah ke alam perkahwinan, Fatimah Hashim mendirikan rumah tangga pada 23 Disember 1943 bersama Abdul Kadir Yusof, seorang yang tidak asing sebenarnya dalam perjuangan politik UMNO (Azizah, 1990: 26). Bekerja sebagai penjawat awam, suami Fatimah Hashim pernah memegang jawatan sebagai Peguam Negara sejak tahun 1964 hingga persaraan pada tahun 1969. Malah, Abdul Kadir dilantik semula sebagai Peguam Negara dan Menteri Undang-undang pada bulan Julai 1969 dan ditukarkan ke Kementerian Kemajuan Tanah dan Pembangunan Wilayah (Azizah, 1990: 32). Peranan Abdul Kadir di atas pentas siasah tidak menonjol seperti isterinya, Fatimah Hashim. Walaupun demikian, Abdul Kadir menceburi dunia politik lebih awal iaitu dari tahun 1945. Bagi Fatimah Hashim pula, beliau mendaftar sebagai ahli UMNO di cawangan Kampung Nong Chik, Johor Bahru pada tahun 1946 ketika usia muda 22 tahun dengan nombor ahlinya 350 (Nik Safiah dan Rokiah, 2003: 1).

Meskipun Cikgu Hashim beralih angin meninggalkan UMNO untuk menyertai Parti Negara pimpinan Dato' Onn Jaafar, Fatimah Hashim tidak mengikut jejak bapanya. Sebaliknya, beliau terus setia bersama UMNO. Sikap Fatimah Hashim yang setia bersama UMNO membuktikan prinsip politik beliau bukan politik ikut-ikutan (Nik Safiah dan Rokiah, 2003: 9). Atas semangat mempertahankan prinsip, setelah sedekad bergelar ahli, Fatimah Hashim dipilih memegang jawatan Ketua Kaum Ibu UMNO kebangsaan pada tahun 1956. Sebelum itu, Fatimah Hashim menjadi Ketua Kaum Ibu UMNO di Kota Tinggi, Johor. Kemudian, atas dasar kepercayaan terhadap kebolehan Fatimah Hashim, semasa mengikuti suami berpindah tempat kerja di Ipoh, Perak, beliau memegang jawatan sebagai Ketua Bahagian Pergerakan Kaum Ibu UMNO Kawasan IpohMenglembu, Ketua Perhubungan Kaum Ibu UMNO dan Ketua Pergerakan Kaum Ibu UMNO Perak.

Dalam kerajaan, Fatimah Hashim ialah Ahli Dewan Rakyat bagi Parlimen Jitra-Padang Terap untuk tiga penggal berturut-turut, dari tahun 1959 hingga 1974. Fatimah Hashim merupakan Menteri Kebajikan Am, bermula dari 20 Mei 1969 hingga akhir bulan Februari 1973. Selain dalam kerajaan, Fatimah Hashim bergiat dalam masyarakat sivil iaitu NCWO, sebuah gabungan organisasi wanita di Malaysia. Pada penggal pertama (1962-1965), Fatimah Hashim terpilih sebagai Timbalan Yang Dipertua. Selanjutnya, pada penggal kedua, Fatimah Hashim dilantik sebagai Yang Dipertua. Jawatan tersebut dipegang hingga tahun 1989, selama 24 tahun (PERTIWI, 2004: 130-133).

\section{TEORI KEPIMPINAN}

Sumber maklumat mengenai kehidupan peribadi dan penglibatan rasmi Fatimah Hashim terdiri daripada sumber primer dan sekunder yang tersimpan dalam pelbagai bentuk seperti kajian biografi, laporan akhbar, surat dan diari peribadi. Akan tetapi, maklumat tersebut akan terus terbiar sekiranya tiada ikhtiar untuk 
menaikkan nilainya untuk menghurai, mentafsir dan menyokong perbincangan teoritis. Ia menjadi komponen empirik yang melandasi ilmu kepimpinan wanita bernuansa tempatan.

Bagi membincangkan aspek teoretis soal kepimpinan dan konsep yang berkait dengannya, ia dimulakan dengan takrif umum "kepimpinan" oleh Wazir (1981), Nik Safiah (1990) dan Northouse (2007). Kemudian, kepimpinan wanita disentuh menerusi sudut pandang Islam dengan mengetengahkan hujah oleh Andek Masnah (1999) dan Ibrahim (2010). Oleh sebab kekangan wanita menjadi pemimpin turut diselidik menerusi pengalaman kepimpinan Fatimah Hashim, perbahasan oleh Eagly dan Carli (2007) dalam Through the Labyrinth: The Truth About How Women Become Leaders turut diketengahkan. Lebih penting, penjelasan teoretis kepimpinan wanita konteks Malaysia dibincangkan untuk menyerlahkan citra kepimpinan wanita tempatan.

\section{Konsep Kepimpinan}

Lazimnya, kepimpinan ditakrif dalam konteks hubungan kuasa antara pemimpin dengan pengikut. Pemimpin dianggap berkuasa, sekali gus berkeupayaan membawa perubahan terhadap para pengikutnya. Menurut Wazir (1981), kepimpinan ialah keupayaan wanita untuk melibatkan diri, merekrut dan mengurus orang lain dalam kegiatan melibatkan khalayak umum, melangkaui lingkungan keluarga atau jaringan kekerabatan. Tidak jauh berbeza, bagi Northouse (2007: 3), kepimpinan ditakrif sebagai, "A process whereby an individual influences a group of individuals to achieve a common goal". Tambah Northouse lagi, kepimpinan wujud dalam dua bentuk iaitu (1) kepimpinan tret, dan (2) kepimpinan proses. Kepimpinan tret merujuk kepada kalimat "she is a natural leader" dan "born to be a leader". Kepimpinan tret menyifatkan seseorang memiliki keistimewaan atau perwatakan atau kualiti yang melayakkannya menjadi pemimpin. Sementara itu, kepimpinan proses menekankan interaksi di antara pemimpin dengan pengikut yang mana seseorang diasah bakat dan kemahiran kepimpinannya menerusi pendidikan proses sosialisasi (Northouse, 2007: 4-5).

Melihatkan kepada penekanan pemimpin dilahirkan menerusi proses sosialisasi pendidikan, Nik Safiah (1990) berpendapat, "pemimpin tidak lahir dengan bakat dan keupayaan untuk memimpin. Pemimpin perlu dibentuk, dipupuk dan dilengkapkan dengan kemahiran-kemahiran tertentu". Sehubungan itu, kursus-kursus kepimpinan wanita diperlukan untuk memperkaya ilmu pengetahuan dan latihan supaya pemimpin wanita lebih berkebolehan dan berkesan. Adapun demikian, sama ada pemimpin lahir kerana bakat semula jadi ataupun menerusi latihan, kepimpinan akan bermakna jika ia memenuhi pendefinisian kepimpinan oleh Nik Safiah (1990) iaitu "keupayaan mempengaruhi serta meyakini orang lain untuk berusaha ke arah sesuatu matlamat sehingga tahap kejayaan". Dalam hal ini, wanita hendaklah tidak 
memencilkan tanggungjawab kepimpinan dalam urusan rumah tangga per se, malah berkecimpung dalam pembangunan masyarakat dan negara.

\section{Dimensi Pembangunan Kepimpinan Wanita: Antara Batasan dengan Ruang}

Kajian ini tertumpu kepada isu kepimpinan pada era kolonial dan pascakolonial iaitu apabila kontinum pemodenan berperanan untuk menggerakkan perubahan masyarakat Malaysia. Pemodenan tersebut, malangnya meminggirkan wanita. Ia melambatkan dan mengehadkan peluang wanita untuk berkecimpung dalam domain pendidikan, politik dan ekonomi moden. Meskipun wanita ada berperanan sebagai pemimpin, bilangannya yang kecil menimbulkan suatu persoalan. Apatah lagi, wanita seakan-akan dikekang daripada menjawat tingkat jawatan atasan dalam strata kepimpinan.

Menjawab persoalan tersebut, Hoyt (2007) menjelaskan kekurangan jumlah wanita dalam kepimpinan peringkat atasan akibat tiga faktor. Pertama, faktor modal insan merangkumi isu taraf pendidikan, pengalaman kerja dan konflik kerjaya-rumah tangga. Kedua, faktor gender menimbulkan soal gaya dan keberkesanan kepimpinan, komitmen, motivasi, promosi diri dan kemahiran perundingan. Ketiga, faktor prejudis terhadap wanita membentuk stereotaip gender, penilaian dan persepsi bias terhadap kepimpinan wanita (Hoyt, 2007: 270-278). Isu kekangan ini memerlukan perhatian lanjut. Bahagian seterusnya membincangkan isu kepimpinan wanita daripada sudut pandang Islam, pengalaman masyarakat Barat dan kupasan bernuansa tempatan.

\section{Kepimpinan wanita daripada kaca mata Islam}

Kaca mata Islam penting kerana ia merupakan epistemologi kehidupan masyarakat Melayu yang mempengaruhi sikap mereka terhadap isu kepimpinan wanita. Andek Masnah (1999) mencerakinkan kepimpinan wanita kepada tiga domain iaitu (1) diri sendiri, (2) rumah tangga, dan (3) masyarakat. Ketigatiganya tidaklah terpisah, tetapi saling berinteraksi antara satu sama lain. Bagi seorang pemimpin wanita, ciri-cirinya adalah sama seperti pemimpin lelaki iaitu (1) Islam, (2) baligh, (3) berakal, (4) merdeka, (5) berilmu, (6) bertakwa kepada Allah, (7) berwibawa, dan (8) tidak cacat pancaindera sehingga boleh menjejaskan peranan kepimpinan (Andek Masnah, 1999: 160).

Meskipun ajaran Islam tidak menghalang wanita berperanan sebagai pemimpin, para ulama berbeza pendapat tentang keharusan wanita sebagai pemimpin. Antaranya, batasan terhadap wanita berlandaskan firman Allah S.W.T. bahawa, "Kaum lelaki itu adalah pemimpin dan pengawal yang bertanggungjawab terhadap kaum perempuan, oleh kerana Allah telah melebihkan orang lelaki (dengan beberapa keistimewaan) atas orang-orang perempuan" (The Noble Qur'an, an-Nisa' 4: 34). Bagaimanapun, dalam al-Quran, dinyatakan bahawa wanita dan lelaki adalah saling bekerjasama, termasuklah 
dalam urusan pembangunan ummah, negara dan agama (The Noble Qur'an, al-Taubah 9: 71).

Kepimpinan wanita dalam Islam mempunyai batasan tertentu yang digariskan oleh ajaran Islam sepertimana nabi dan rasul tidak dilantik dalam kalangan wanita. Selain itu, wanita tidak diizinkan untuk memimpin solat yang dihadiri oleh jemaah lelaki dan tidak diharuskan menjadi ketua tentera. Kekangan ini dirasionalkan oleh fitrah, tabiat dan risalah penciptaan wanita (Andek Masnah, 1999: 158-159).

Menyentuh isu wanita dalam kepimpinan dan dunia politik, Ibrahim (2010) menegaskan bahawa golongan wanita Islam adalah tidak bersalahan dengan hukum-hakam agama sekiranya mereka berkecimpung dalam kegiatan politik. Namun begitu, penglibatan wanita mestilah tidak mengganggu dan mengurangkan keutamaan peranan dalam institusi kekeluargaan iaitu tanggungjawab terhadap suami dan anak-anak.

\section{Liku-liku kepimpinan wanita dalam konteks Barat}

Kebanyakan perbahasan isu kepimpinan wanita dibangunkan mengikut konteks masyarakat, terutama daripada perspektif dunia Barat. Secara kasar, ia mampu membentuk kefahaman awal mengenai isu kepimpinan wanita Malaysia. Bahagian ini membawakan perbahasan oleh Eagly dan Carli (2007) tentang likuliku yang menghalang wanita menduduki jawatan kepimpinan peringkat tertinggi, berdasarkan konteks negara Amerika Syarikat. Ia menerbitkan tiga konsep yang terhasil daripada pematangan perbahasan akademik iaitu (1) dinding konkrit, (2) siling kaca dan (3) labyrinth.

Menurut Eagly dan Carli (2007), ketajaman fungsi analitikal "dinding konkrit" telah pun tumpul. Ia menjadi tembok kental yang menghalang wanita daripada diiktiraf sebagai pemimpin, meskipun amalan demokrasi Amerika Syarikat telah menjamin hak pengundian wanita sejak tahun 1920. Antara sebab utama yang menghalang wanita menerajui kepimpinan ialah taraf pendidikan dan belenggu sikap prejudis. Presiden Amerika Syarikat, Richard Nixon, menjelaskan mengapa wanita tidak dilantik sebagai hakim di peringkat Supreme Court, bahawa, "I don't think a woman should be in any government job whatsoever... The reason why I do is mainly because they are erratic. And emotional. Men are erratic and emotional, too, but the point is a woman is more likely to be" (Eagly dan Carli, 2007: 3).

Selain itu, kebanyakan organisasi bersikap prejudis wanita. Peluang temu duga bidang profesional untuk wanita dihadkan. Wanita disisih daripada menceburi kerjaya yang disinonimkan, sekali gus didominasi oleh lelaki. Persekitaran tidak mesra wanita wujud kerana budaya patriarki yang cenderung meletakkan wanita di rumah. Domain rumah tangga secocok dengan konstruk gender wanita - nurture, selain dihalang oleh peranan biologi sebagai ibunature. Walaupun dinding konkrit berupaya mengungkap realiti kepimpinan 
wanita sekitar pertengahan abad ke-20, segelintir individu wanita cuba untuk merobohkannya. Namun, rata-rata wanita tidak mempersoalkannya atas isu diskriminasi, bahkan menganggap ia sebagai kebiasaan (Eagly dan Carli, 2007: 3).

Konsep "siling kaca" mula membangun pada tahun 1986 apabila wartawan Wall Street Journal, Caroll Hymowitz dan Timothy Schellhardt menggunakannya sebagai metafora untuk menjelaskan pendakian wanita dalam kerjaya. Metafora siling kaca memaparkan senario dekad 1970-an. Wanita berkerjaya mendaki kedudukan jawatan, peringkat demi peringkat, tetapi tiba-tiba terhalang daripada memegang jawatan tinggi yang secara tradisinya didominasi lelaki (Eagly dan Carli, 2007: 4). Pilihan wanita sendiri untuk mencurahkan komitmen dalam urusan keluarga seperti mengasuh anak-anak menjadi alasan mengapa wanita kekal pada tingkat jawatan yang rendah. Selain itu, majikan mendakwa bahawa klien kurang selesa untuk berurusan dengan pekerja wanita. Sikap ini mengakibatkan golongan wanita terus terpasung daripada memegang jawatan tertinggi dalam organisasi (Eagly dan Carli, 2007: 5).

Seiringan dengan realiti wanita dalam dunia kepimpinan, konsep siling kaca mula retak. Ia dikritik oleh Eagly dan Carli (2007) dengan mengemukakan tujuh hujah yang membidas siling kaca sebagai konsep tumpul untuk mengupas realiti kemajuan wanita dalam kepimpinan. Pertama, wujud tanggapan salah bahawa wanita memiliki peluang sama terhadap jawatan, walhal wanita dihalangi lapisan-lapisan sikap prejudis dan diskriminasi. Kedua, ia menganggap halangan terhadap wanita bersifat mutlak untuk satu-satu tingkat jawatan khusus, sedangkan ia boleh diterobosi. Ketiga, ia membina keadaan fikiran bahawa kekangan terhadap wanita sukar untuk dikesan dan dijangkakan. Keempat, ia mengandaikan wanita dibataskan oleh faktor tunggal semata-mata, padahal kekangan terdiri daripada pelbagai faktor. Kelima, ia gagal mengenal pasti kepelbagaian strategi untuk mengupayakan wanita menjadi pemimpin. Keenam, ia menafikan kemungkinan wanita untuk meruntuhkan kekangan menjadi pemimpin. Ketujuh, ia gagal merungkai akar permasalahan yang boleh membuka jalan kepada wanita ke arena kepimpinan.

Oleh itu, setakat masa ini, konsep labyrinth menjelaskan bagaimana individu wanita terpaksa mengharungi kekangan berliku lagi berselirat untuk ke jawatan atasan. Mereka terpaksa berdepan dengan berbagai-bagai rintangan untuk membina kerjaya. Bermula daripada bebanan tanggungjawab biologikal sebagai seorang isteri dan ibu, wanita menghadapi halangan budaya daripada ahli keluarga seterusnya prejudis dalam masyarakat. Liku-liku sebegini berterusan di tempat kerja atas faktor gender. Realiti sebegini menimbulkan persoalan, bagaimanakah Fatimah Hashim berjaya memegang jawatan beraras tinggi, khususnya Menteri Kebajikan Am, sekali gus menteri pertama dalam kalangan wanita Malaysia? Bagi meneliti isu ini dalam konteks kepimpinan di Malaysia, amatlah perlu untuk kita mengurai dan mengulit kembali secara historis, seraya 
mempertimbangkan penjelasan konseptual kepimpinan wanita seperti dinukilkan sarjana dalam konteks Malaysia.

\section{Isu kepimpinan wanita bernuansa tempatan}

Pertimbangan perbahasan isu kepimpinan wanita berdasarkan konteks tempatan sejajar dengan gagasan "pemeribumian Sains Sosial" (the indigenization of the Social Sciences) yang diutarakan Syed Farid (1994) dalam penteorian feminisme bernuansa tempatan. Pemeribumian Sains Sosial dinyatakan oleh Syed Farid (1994) sebagai suatu gagasan pemikiran mengenai ilmu beracuan tempatan iaitu, "The grounding of the human and social sciences in indigenous philosophies, epistemologies and histories".

Beberapa sarjana yang menyelidiki kepimpinan wanita dalam konteks Malaysia secara tidak langsung menyentuh konteks kepimpinan Fatimah Hashim. Bagi Wazir (1981), perkembangan kepimpinan wanita Melayu di Semenanjung Malaysia didorong oleh (1) faktor struktural, dan (2) faktor pemasyarakatan dan pendidikan. Faktor-faktor struktural tersebut ialah (1) perjuangan kemerdekaan yang bersifat nasionalisme antikolonial, (2) peranan sistem pendidikan Arab atau agama, (3) kepentingan wanita sebagai penyokong isu-isu politik negara, dan (4) sistem kekerabatan yang memberatkan kedua-dua golongan lelaki dan wanita serta mengizinkan wanita bebas bergerak di luar lingkungan keluarga. Faktor pemasyarakatan dan pendidikan pula ialah (1) sistem pemasyarakatan liberal yang membenarkan kanak-kanak perempuan untuk bertingkah laku seperti kanak-kanak lelaki, (2) kepentingan pendidikan formal kanak-kanak perempuan dalam keluarga elit Melayu kawasan desa dan bandar, (3) dorongan suami dan anak-anak, (4) sikap suka untuk mencabar diri sendiri, dan (5) kesabaran, keberanian serta ketekunan dalam diri yang membentengi matlamat politik pemimpin wanita daripada digugat tekanan semasa.

Sejarawan Ramlah (1993) pula meninjau kepimpinan awal Pergerakan Wanita UMNO yang merupakan medan kepimpinan Fatimah Hashim. Ramlah mendapati kepimpinan awal Kaum Ibu UMNO mempunyai para pemimpin yang sekurang-kurangnya mempunyai pertalian kekeluargaan dengan sesiapa sahaja pemimpin lelaki dalam parti politik. Bahkan, kebanyakan pelantikan pemimpinnya juga dilaksanakan semata-mata atas faktor pertalian keluarga. Walaupun begitu, seorang pemimpin wanita hendaklah membuktikan kemampuan meritnya serta boleh memberikan tunjuk ajar kepada wanita yang dipimpin dalam organisasi.

Oleh sebab fokus kajian ini adalah terhadap salah seorang pemimpin ataupun Ketua Kaum Ibu UMNO, terdapat beberapa kajian yang juga melihat isu kepimpinan tokoh Ketua Kaum Ibu UMNO. Zaharah (2000) menyelidiki kepimpinan Ketua Kaum Ibu UMNO kontroversial Khatijah Sidek. Manakala Mahfudzah (2000) pula mengkaji seorang lagi Ketua Kaum Ibu UMNO yang kepimpinannya dikatakan bersifat keibuan iaitu Ibu Zain. Di samping itu, Ting 
(2007) membandingkan dua pemimpin, Fatimah Hashim dan Khatijah Sidek yang berbeza gaya kepimpinannya dalam perjuangan hak wanita iaitu bersifat sederhana (Fatimah Hashim) dan radikal (Khatijah Sidek).

Dalam kajian-kajian terdahulu, acuan kupasan aspek-aspek kepimpinan tokoh wanita dibayangi oleh teori dan konsep para sarjana di luar konteks Malaysia, atau tidak menerapkan elemen teoretis. Oleh yang demikian, kajian ini berhasrat untuk memperkayakan lagi aspek-aspek teoretis dan empiris bagi pembangunan korpus ilmu kepimpinan wanita Malaysia, berdasarkan pengalaman Fatimah Hashim. Sehubungan itu, pembinaan ilmu watan dapat diserlahkan.

\section{Asas-asas Pembangunan Kepimpinan Wanita: Pendidikan, Lingkungan Sosial dan Konteks Sejarah}

Berdasarkan perbincangan perkembangan awal kepimpinan politik wanita Melayu, dapatlah dibina kerangka untuk menjelaskan isu kepimpinan Fatimah Hashim. Terdapat tiga asas yang didapati mempengaruhi pembangunan kepimpinan wanita berlandaskan pengalaman Fatimah Hashim, iaitu (1) pendidikan: sama ada formal atau tidak formal, (2) lingkungan sosial: sama ada keluarga ataupun rakan-rakan, dan (3) konteks sejarah. Tiga aspek ini dijelaskan dalam bahagian seterusnya.

\section{Peranan pendidikan: Formal dan tidak formal}

Menyentuh peranan pendidikan sebagai pendorong wanita ke dunia kepimpinan, Saliha (1994) menilai pengaruh pendidikan formal dan tidak formal terhadap pembangunan politik wanita. Pendidikan formal merujuk kepada pendidikan yang direncana mengikut kehendak pihak kerajaan. Sementara itu, pendidikan tidak formal diperoleh daripada sosialisasi atau pengalaman semasa bercampur gaul bersama ahli keluarga dan rakan-rakan atau entiti bukan kerajaan seperti media massa. Dalam hal pembangunan politik wanita, pendidikan tidak formal dilihat lebih berperanan untuk mendorong golongan wanita ke dalam dunia kepimpinan politik.

Bagi jenis pendidikan formal, persepsi umum bahawa pendidikan moden aliran Inggeris bertanggungjawab melahirkan barisan kepimpinan wanita perlu ditangani (Manderson, 1978; Jamilah, 1992). Sekiranya tanggapan ini diperhatikan dengan teliti, jenis pendidikan yang lebih awal melahirkan pemimpin politik wanita Melayu dalam Angkatan Wanita Sedar (AWAS) ialah sistem pendidikan aliran agama. Tokoh-tokoh pemimpin AWAS seperti Aishah Ghani, Sakinah Junid dan Shamsiah Fakeh terdidik dalam sekitaran kebangkitan semangat nasionalisme di sekolah agama Diniyah Puteri, Padang Panjang, Sumatera Barat, Indonesia (Wazir, 1992). 
Di samping itu, aliran pendidikan formal pra-Perang Dunia Kedua di Tanah Melayu tidak berperanan secara objektif untuk melahirkan pemimpin politik wanita. Hal ini kerana pendidikan aliran Melayu dan Inggeris adalah berorientasikan pelajaran kemahiran rumah tangga yang bertujuan untuk menyediakan wanita sebagai seorang ibu atau isteri yang lebih baik. Memetik kata-kata oleh Tan (1981), "Most of the women therefore were content to become more accomplished housewives and better companions to their husbands after receiving a basic education". Dengan orientasi demikian, rata-rata pemimpin wanita pada era pra Perang Dunia Kedua bergiat dalam persatuan bercorak kebajikan, lantas memperkukuh peranan tradisi wanita Melayu.

Sehubungan itu, peranan pendidikan tidak formal ternyata lebih berpengaruh untuk mendorong wanita melibatkan diri dalam politik, seterusnya menjadi pemimpin organisasi politik. Selari dengan pendapat Saliha (1994), "In the area of political participation, there are other factors that may be influential than formal education. For that matter, informal education plays a more significant role". Pendidikan tidak formal berkait rapat dengan hubungan kemasyarakatan wanita dalam lingkungan keluarga dan rakan-rakan. Dalam bahagian selanjutnya, perbincangan ini menyentuh peranan ikatan sosial sebagai faktor sosialisasi kepimpinan wanita.

\section{Peranan lingkungan sosial}

Sepertimana dihujahkan oleh Wazir (1981) berkenaan kepimpinan Kaum Ibu UMNO, "Early Kaum Ibu leaders were the wives of existing leaders of UMNO, who were encouraged by their husbands to take an active interest in the affairs of the party", Ramlah (1993) juga mengakui keakraban hubungan sesetengah pemimpin wanita Kaum Ibu UMNO dengan golongan elit politik lelaki dalam parti politik. Ia menjadi faktor penyaluran wanita ke dalam struktur kepimpinan parti. Berkenaan hal ini, kepimpinan Pergerakan Kaum Ibu UMNO secara umum terstruktur kepada tiga peringkat iaitu (1) akar umbi, (2) bahagian dan negeri, dan (3) pusat. Pada setiap peringkat, terdapat kecenderungan untuk mengutamakan wanita berpendidikan formal bagi jawatan atasan kepimpinan parti. Di peringkat akar umbi, meskipun mustahak, taraf pendidikan bukanlah bersifat penentu tetapi kemahiran kepimpinan yang disaduri prestij kelas sosial.

Perlu ditekankan, faktor kelas sosial memiliki pengaruh kuat terhadap struktur kepimpinan dalam masyarakat Melayu. Walaupun kepimpinan masyarakat Melayu tradisional mula mengalami pemodenan pada era kolonial, golongan yang membentuk strata kepimpinan moden sebahagian besarnya merupakan keturunan raja atau bangsawan. Keadaan ini berlaku kerana pemodenan pendidikan dan pentadbiran telah dibuka kepada kelas sosial atasan (Manderson, 1980: 7-9). Berikutan itu juga, wanita daripada kelas sosial atasan ataupun berpengaruh dalam satu-satu komuniti dilibatkan sama dalam urusan kepimpinan. Lazimnya, pemimpin wanita akar umbi ialah anak dan isteri kepada 
individu yang berpengaruh dalam masyarakat kampung, suri rumah tangga, berkahwin dan tidak berpekerjaan tetap. Begitu juga keadaannya di peringkat bahagian dan negeri, status kelas sosial wanita diutamakan selain pendidikan formal peringkat rendah dan berkebolehan mengajar ilmu kemahiran seperti jahitan dan seni. Di peringkat pusat, taraf pendidikan diutamakan. Pemimpin Kaum Ibu UMNO ialah wanita yang berpendidikan, sama ada daripada vernakular Melayu atau aliran Inggeris. Bagaimanapun, pendidikan tinggi sahaja tidak memadai. Faktor kelas sosial menjadi ciri terpenting pemimpin politik wanita. Perkara ini dinyatakan oleh Ramlah (1993) bahawa, "Di peringkat tertinggi Pergerakan Kaum Ibu ia dikuasai oleh mereka yang berlatarbelakangkan kekuatan politik dan sosial keluarga".

Hakikatnya, faktor kelas sosial adalah signifikan untuk memahami kepimpinan masyarakat Melayu, tidak terkecuali kepimpinan politik wanita. Manderson (1987) ada menyatakan, "They have been the daughters, wives and sisters of elite men, in Malaysia both from the aristocracy and from the Englisheducated elite". Namun, kenyataan ini perlu dihalusi kerana bukan semua pemimpin wanita Melayu berasal-usul daripada keluarga bangsawan dan berpendidikan aliran Inggeris. Selain itu, para pemimpin wanita yang mempunyai hubungan erat dengan golongan elit politik lelaki sering kali distereotaipkan dengan Kaum Ibu UMNO. Dalam tinjauan Muhammad Rahimi (2014) secara sepintas lalu terhadap kepimpinan wanita Melayu pramerdeka, ciri pertalian keluarga tidak eksklusif kepada pemimpin Kaum Ibu UMNO sahaja, malahan AWAS. Para pemimpin AWAS rata-ratanya merupakan anak atau isteri pemimpin lelaki dalam Angkatan Pemuda Insaf (API). Hal ini bermakna, pertalian keluarga pemimpin wanita dan golongan elit politik lelaki ialah ciri kepimpinan wanita Melayu — setidak-tidaknya terbukti melalui Kaum Ibu UMNO dan AWAS. Begitupun, bakat dan kemahiran kepimpinan itulah yang melayakkan seseorang wanita dinobatkan sebagai pemimpin.

\section{Peranan konteks sejarah}

Pengalaman peribadi pemimpin wanita bercampur gaul dalam konteks sejarahnya adalah lebih luas. Persekitaran ini mencorakkan keprihatinan kepimpinan. Pemimpin wanita terbentuk hasil pengalaman sejarah dan peribadi yang ditempuhi sepanjang kehidupan. Penekanan pengalaman peribadi dalam konteks sejarah luas menjadi dimensi penting untuk memahami kepimpinan wanita, sama ada "sejarah wanita" secara khusus ataupun "sejarah negara" secara am.

Sehubungan dengan konteks sejarah wanita, kepimpinan Fatimah Hashim telah diwarnai oleh tiga tahap gerakan wanita Malaysia yang diistilahkan oleh $\mathrm{Ng}$, Maznah dan Tan (2006) sebagai fasa (1) nationalist feminism, (2) social feminism, dan (3) political feminism. Nationalist feminism yang berlangsung semasa era pramerdeka menekankan tuntutan hak wanita dalam politik, ekonomi dan sosial sebagai terintegrasi dalam perjuangan kemerdekaan negara. Kedua, 
fasa social feminism bermula pada tahun 1958 sehingga 1969 memperlihatkan wanita sebagai fokus undang-undang baharu seperti hak sama rata dalam bidang pekerjaan. Pada masa itu, NCWO ditubuhkan untuk menaungi organisasi wanita, selain berusaha menggerakkan institusi moden dan menggubal undang-undang supaya lebih berkesan dalam membawa kebaikan kepada wanita. Ketiga, fasa political feminism sejak awal dekad 1970-an sehingga akhir 1990-an menyaksikan kemunculan gerakan wanita yang berautonomi dan bergiat melobi reformasi undang-undang. Isu wanita diartikulasikan secara spesifik seperti keganasan terhadap wanita atau violence against women (VAW) pada dekad 1980-an. Malah, VAW diselarikan dengan agenda hak asasi manusia.

Lebih khusus, kepimpinan politik Fatimah Hashim dilatari dimensi ideologikal yang diutarakan oleh Rashila dan Saliha (1998). Kepolitikan di Malaysia diwarnai oleh keberagaman ideologi, agama, etnik, kewilayahan dan kelas; sama ada kelas ekonomi mahupun kelas sosial. Selain itu, terdapat ideologi dominan yang mendasari fasa-fasa politik di Malaysia. Sekitar dekad 1940-an hingga 1960-an, politik wanita dipengaruhi arus ideologi nasionalisme, berkerajaan sendiri dan pembinaan negara bangsa. Dekad 1970-an dan 1980-an pula, penglibatan wanita dalam lapangan politik dan ekonomi didorong oleh program pembandaran, perindustrian dan pemodenan yang ditatakelola suatu matriks dasar awam yang mengiktiraf dan meletakkan golongan wanita sebagai enjin pembangunan negara. Dasar Ekonomi Baru (DEB) yang diwujudkan hasil krisis etnik yang begitu tempatan sekali sifatnya telah bertembung dengan kedinamikan perkembangan peringkat global. Fenomena sedemikian menjurus ke arah terbinanya suatu matriks yang mendorong golongan wanita Malaysia untuk diiktiraf, sekali gus dilibatkan bersama dalam proses pembangunan negara. Komitmen pihak Kerajaan Malaysia terhadap agenda Women in Development (WID) dan penganjuran Dekad Wanita Antarabangsa (1975-1985) meningkatkan penglibatan awam wanita dalam lapangan politik dan ekonomi. Selain itu, wujudnya Majlis Penasihat Kebangsaan Mengenai Integrasi Wanita dalam Pembangunan (NACIWID) dan Dasar Wanita Negara (1989) menjadi manifestasi kepentingan penglibatan wanita dalam agenda pembangunan (Nik Safiah, 1985; Rashila, 1995; Ng, Maznah dan Tan, 2006).

\section{PEMBANGUNAN KEPIMPINAN WANITA FATIMAH HASHIM}

Suami Fatimah Hashim pernah menyatakan bahawa, "Dari awal-awal lagi saya lihat Tan Sri Fatimah seorang yang dikatakan 'a born leader'" (Azizah, 1990: 31). Kenyataan ini menimbulkan persoalan tentang bagaimanakah Fatimah Hashim boleh dibuktikan sebagai a born leader? Hal ini kerana pembangunan kepimpinan Fatimah Hashim lahir melalui proses sosial. Pembangunan kepimpinan beliau didorong oleh proses sosialisasi dalam lingkungan keluarga dan rakan-rakan. Negeri kelahiran beliau, Johor, ialah markas nasionalis Melayu. 
Bahkan, di negeri Johorlah terbentuknya parti politik yang menyatupadukan persatuan-persatuan Melayu berteraskan ideologi nasionalisme kenegerian kepada pertubuhan kebangsaan bernama UMNO. Ia mewujudkan sekitaran kondusif yang mendorong dan memupuk pembangunan kepimpinan Fatimah Hashim (Nik Safiah dan Rokiah, 2003: 7). Sehubungan itu, pembangunan kepimpinan Fatimah Hashim dijelaskan dan difahami berdasarkan beberapa asas. Setiap asas tersebut dihuraikan dalam bahagian-bahagian seterusnya.

\section{Pendidikan Formal: Pendedahan Awal ke Dunia Kepimpinan}

Beberapa sarjana menyatakan pendidikan formal aliran Inggeris berperanan merekrut pemimpin wanita Melayu (Manderson, 1987; Jamilah, 1992). Kenyataan kepimpinan wanita berasal daripada keluarga bangsawan dan berpendidikan aliran Inggeris kurang sesuai dengan Fatimah Hashim. Beliau merupakan anak perempuan dan isteri kepada elit lelaki UMNO tetapi bukan berpendidikan Inggeris. Fatimah Hashim dididik dalam aliran vernakular Melayu hingga darjah lima sahaja. Sehubungan itu, Fatimah Hashim berlainan dengan Ketua Kaum Ibu UMNO sebelumnya yang berpendidikan Inggeris iaitu Puteh Mariah Ibrahim Rashid, Ibu Zain dan Khatijah Sidek. Malahan, berlainan dengan para pemimpin Wanita UMNO selepas itu yang merupakan angkatan baharu pemimpin wanita Melayu berkelulusan pengajian tinggi atau universiti seperti Aishah Ghani dan Rafidah Aziz (Manderson, 1980; Dancz, 1987).

Meskipun pendidikan formal tidak berperanan secara objektif untuk sosialisasi kepimpinan, pengalaman di sekolah memberikan Fatimah Hashim pendedahan awal sebagai pemimpin. Beliau menjadi ketua kepada rakan-rakan semasa berada di bangku persekolahan. Antaranya, Fatimah Hashim pernah berperanan selaku ketua darjah, ketua kumpulan murid-murid perempuan, ketua kumpulan untuk murid perempuan dalam kegiatan berkebun sayur, Ketua Murid Sekolah Melayu Perempuan Mersing dan ketua rombongan pasukan senaman sekolah pada peringkat negeri Johor (PERTIWI, 1983). Peranan sebagai pemimpin atau ketua lingkungan sosial di sekolah ini menyemai bibit-bibit awal bakat kepimpinan Fatimah Hashim. Kualiti kepimpinan mula diasah melalui sosialisasi kepimpinan tidak formal dalam lingkungan sosial iaitu keluarga dan teman seperjuangan politik.

\section{Ahli Keluarga (Lelaki): Pemangkin ke Dunia Kepimpinan}

Sepertimana ditekankan oleh Saliha (1994), pendidikan tidak formal lebih berpengaruh terhadap pembangunan politik wanita. Bagi Fatimah Hashim sendiri, beliau memperoleh pendidikan tidak formal daripada keluarga dan sahabat handai. Lingkungan kekeluargaan menjadi pemangkin Fatimah Hashim untuk berkecimpung dalam kancah politik yang begitu asing bagi wanita. Berkali-kali peranan ahli keluarga Fatimah Hashim dikupas dan diulas para 
sarjana. Wazir (1981) menyatakan bahawa pelantikan Fatimah Hashim sebagai Ahli Majlis Tertinggi UMNO pada tahun 1959 berkait rapat dengan kerjaya suami beliau dalam UMNO dan kerjayanya dalam bidang undang-undang sebagai Timbalan Pendakwa Raya di Ipoh seterusnya selaku Peguam Negara. Tambahan pula, keakraban hubungan persahabatan Fatimah Hashim dengan Tunku Abdul Rahman menyerlahkan lagi bakat kepimpinan beliau sebagai justifikasi pelantikan sebagai Ahli Majlis Tertinggi UMNO. Mengenai pengaruh keluarga, Rokiah (2007) juga menghujahkan penglibatan Fatimah Hashim dalam politik adalah kerana sudah terbiasa hidup dalam persekitaran politik. Bapa, suami dan ibu mertua beliau sendiri memegang jawatan politik. Malahan, dalam penulisan oleh Nik Safiah dan Rokiah (2003), sesuatu yang menarik berkenaan penglibatan Fatimah Hashim dalam dunia kepimpinan ialah keterbukaan pemikiran ahli keluarga lelaki beliau terhadap peranan wanita sebagai pemimpin yang jelas sekali mendahului zaman, khususnya bapa dan suami.

Sebagai pemimpin politik wanita yang mendewasa sezaman dengan perjuangan kemerdekaan negara, pertalian keluarga Fatimah Hashim dengan individu berfahaman nasionalis didapati melentur diri Fatimah Hashim sebagai seorang pemimpin bangsa, khususnya wanita. Ibu bapa beliau sememangnya bergiat secara aktif dalam perjuangan kemerdekaan negara. Bapa beliau, Cikgu Hashim, menyokong kuat perjuangan UMNO. Secara tidak langsung, ia menarik minat Fatimah Hashim terhadap perjuangan UMNO membela nasib Melayu. Apabila bapanya beralih angin mengikut Dato' Onn Jaafar menyertai Parti Negara, Fatimah Hashim setia berkhidmat dalam UMNO (Nik Safiah dan Rokiah, 2003).

Selain ahli keluarga sedarah sedaging, sosialisasi kepimpinan Fatimah Hashim juga disuntik oleh keluarga suaminya. Ibu mertua Fatimah Hashim, Puan Safiah, telah bergiat cergas dalam UMNO sejak tahun 1947 iaitu semasa berperanan selaku Ketua Cawangan UMNO Kampung Parit Sakai, Muar. Ketika itu, tiada hatta seorang lelaki, apatah lagi wanita yang berani untuk memikul tanggungjawab kepimpinan UMNO di Kampung Parit Sakai. Suami Fatimah Hashim, Abdul Kadir, sememangnya begitu meminati politik UMNO. Akan tetapi, jawatan sebagai pegawai kerajaan menghalang Abdul Kadir daripada bergiat dalam politik (Nik Safiah dan Rokiah, 2003: 12-13).

Bagi Abdul Kadir, beliau sendiri mendorong Fatimah Hashim untuk mengetengahkan peranan kepimpinan yang mendesak keperluannya untuk membela hak wanita. Tegas Abdul Kadir, aktiviti bercorak kebajikan sahaja tidak begitu berkesan untuk memperbaiki keadaan wanita. Sehubungan itu, strategi yang disarankan kepada Fatimah Hashim untuk membawa perubahan adalah dengan memegang kuasa politik (Azizah, 1990: 31; Nik Safiah dan Rokiah, 2003: 14). Sesungguhnya, pendirian Abdul Kadir jarang sekali ditemui semasa era pramerdeka, bahkan selepas merdeka. Beliau mendorong dan menyokong isterinya untuk membina kerjaya yang lebih berprestij berbanding diri sendiri. Abdul Kadir turut melontarkan pandangannya bahawa wanita mestilah diberikan 
hak perwakilan dalam Parlimen agar isu wanita diambil kira oleh pihak kerajaan (Nik Safiah dan Rokiah, 2003: 16).

Milieu keluarga Fatimah Hashim menggalakkan dan mendorong diri Fatimah untuk berkecimpung dalam politik, seterusnya memimpin. Oleh itu, sebagai pemimpin wanita yang muncul dalam sebuah masyarakat yang masih tebal dengan sikap prejudis terhadap peranan golongan wanita dalam kegiatan awam, ia sesuatu yang mendahului zaman. Berikutan itu, mengikut andaian konsep labyrinth, lingkungan keluarga yang dianggap sebagai liku-liku awal yang mengekang potensi wanita menjadi pemimpin menunjukkan hal sebaliknya. Lingkungan keluarga nyata berperanan mendorong dan memangkin pembangunan diri Fatimah Hashim sebagai pemimpin wanita.

\section{Rakan-rakan: "Persahabatan Merupakan Satu Faktor yang Penting"}

"Persahabatan merupakan satu faktor yang penting" adalah sebaris kalimat yang tercatat dalam diari peribadi Fatimah Hashim (Diari Fatimah Hashim, 1968). Sebagai seorang pencatat yang setia, Fatimah Hashim jarang sekali menukilkan perasaan hati dalam diarinya, melainkan perihal urusan rasmi dan aktiviti pada masa lapang. Maka, kalimat istimewa ini tentunya membawa pengertian penting dalam kehidupan Fatimah Hashim. Kenyataan mengenai persahabatan ini boleh ditelah sebagai menyimpan makna besar dalam hidup Fatimah Hashim, tidak terkecuali dalam dunia kepimpinannya.

Pergaulan dan hubungan rapat bersama rakan-rakan telah mendorong Fatimah Hashim menjadi pemimpin. Beliau dan suami mempunyai hubungan akrab bersama pemimpin awal UMNO seperti Sardon Jubir, Abdul Razak Hussin, Hussein Onn dan Senu Abdul Rahman (Nik Safiah dan Rokiah, 2003: 16). Peranan suami dan rakan-rakan diakui Fatimah Hashim sehubungan dengan pelantikannya sebagai Ketua Kaum Ibu UMNO pada 11 September 1956. Fatimah Hashim hanya bersetuju dengan pelantikan setelah membincangkannya dengan suami dan rakan-rakan. Memetik kata-kata Fatimah, "Saya menerima perlantikan itu hanya setelah disuruh menerimanya oleh suami saya sendiri dan beberapa orang rakan lain seperti Tun Sardon, Tan Sri Khir Johari dan Dato' Senu Abdul Rahman" (Azizah, 1990: 79).

Proses sosialisasi daripada bapa, dorongan dan sokongan daripada suami dan rakan-rakan didapati bertanggungjawab mencetuskan dan membangunkan kepimpinan Fatimah Hashim. Daripada satu sudut, pengalaman kepimpinan Fatimah Hashim memperteguh pandangan konvensional bahawa rata-rata pemimpin Kaum Ibu UMNO ialah isteri atau anak para pemimpin lelaki dalam parti (Wazir, 1981; Ramlah, 1993). Bagaimanapun, dengan menonjolkan peranan ikatan sosial, ini bukan bermakna kewibawaan kepimpinan Fatimah Hashim dipersoalkan. Sebaliknya, mutu kepimpinan dalam diri Fatimah Hashim itulah yang cuba digilap oleh aktor-aktor sekelilingnya, bersesuaian dengan tuntutan semasa untuk melibatkan wanita membangunkan negara. 


\section{Konteks Sejarah: Pembentuk Hala Tuju Kepimpinan}

Fatimah Hashim menempuh kehidupan era pramerdeka. Kesan kolonialisme terhadap bangsanya, lebih-lebih lagi golongan wanita Melayu amat menginsafkan dirinya. Keinginan Fatimah Hashim untuk membela nasib golongan wanita menerusi latihan dan bimbingan mula terbentuk daripada pengalaman peribadi. Semasa sedang sarat mengandungkan anak sulung, beliau turun ke bendang membuat kerja-kerja menanam padi, semata-mata kerana segan dengan ibu mertua, Puan Safiah. Di situlah Fatimah Hashim melihat wanita bekerja berhempas-pulas tetapi tidak diberikan latihan dalam bidang pertanian. Ingatan memori silam beliau ini diterjemahkan menerusi tindakan sebaik dilantik sebagai Menteri Kebajikan Am. Pihak Kementerian Pertanian melalui Maktab Kerjasama di Petaling Jaya dipohon untuk membuka kursus pertanian kepada wanita (Azizah, 1990: 27; Nik Safiah dan Rokiah 2003: 19).

Fatimah Hashim menyedari kemunduran golongan wanita ialah senasib dengan bangsa Melayu yang ditekan kolonialisme. Menyedari hal itu, Fatimah Hashim sering berbincang bersama suami tentang ikhtiar membela nasib wanita dalam pembangunan, seterusnya mencapai kemajuan untuk wanita. Bagi tujuan itu, Fatimah Hashim selalu bertanya-tanya bagaimana matlamat tersebut boleh direalisasikan (Azizah, 1990: 31; Nik Safiah dan Rokiah, 2003: 14). Nampaknya, mutu seorang pemimpin telah tertanam dalam diri Fatimah Hashim. Beliau mempunyai matlamat kepimpinan wanita yang jelas dan berupaya memahami kolonialisme sebagai rangka permasalahan utama yang menjerat golongan wanita daripada bersama arus kemajuan.

Sehubungan itu, langkah awal pembelaan wanita ialah menerusi kemerdekaan negara, iaitu strategi yang disedari sendiri oleh Fatimah Hashim. Semasa merantau ke London, beliau menyaksikan perbezaan tahap kemajuan di negara penjajah dan negara dijajah. Kegeraman terhadap ketidakadilan ini menyemarakkan semangat nasionalisme Fatimah Hashim untuk berjuang ke arah kemerdekaan Tanah Melayu (Nik Safiah dan Rokiah, 2003: 28-29). Sikap antikolonial Fatimah Hashim yang berbaur dengan soal gender berterusan setelah merdeka. Menyentuh tanggungjawab wanita dalam pembangunan negara, Fatimah Hashim mendakwa penjajahan merosakkan semangat juang wanita hingga hilang keyakinan diri. Oleh itu, wanita memerlukan latihan untuk menghapuskan sifat-sifat yang menghalang kemajuan (Utusan Melayu, 9 Januari 1961). Berdasarkan penjelasan ini, pengalaman sejarah, baik pengalaman yang bersifat peribadi ataupun pengalaman di bawah kongkongan kolonialisme, telah mencetus dan menghalakan matlamat kepimpinan Fatimah Hashim ke arah agenda golongan wanita. 


\section{EMPAT DEKAD DI PERSADA KEPIMPINAN: SUARA PEMBELAAN HAK WANITA FATIMAH HASHIM}

Tempoh empat dekad yang begitu panjang bagi Fatimah Hashim boleh dihubung kait dengan gaya kepimpinan beliau yang jelas tidak menunjukkan unsur provokatif untuk menuntut hak wanita. Tegasnya, wanita sebagai penyokong dalam struktur parti politik dipengaruhi kelangsungan politiknya oleh gaya kepimpinan. Ketua Kaum Ibu UMNO Khatijah Sidek yang lantang bersuara dan sering kali menimbulkan konfrontasi dengan pemimpin parti apabila mengartikulasikan hak wanita, ternyata gagal bertahan dalam politik UMNO. Berlainan dengan Fatimah Hashim, beliau cenderung menggunakan perundingan untuk menuntut hak wanita. Gaya kepimpinan moderat Fatimah Hashim yang disenangi pucuk pimpinan parti membolehkan jawatan Ketua Kaum Ibu UMNO dipertahankan selama 16 tahun lamanya (Kamilia, 1998; Ting, 2007).

Bermula menerusi Kaum Ibu UMNO, kehadiran Fatimah Hashim selama empat dekad di persada kepimpinan adalah tempoh yang lama untuk menjalankan langkah-langkah pembelaan hak wanita di Malaysia. Fatimah Hashim turut berperanan sebagai pemimpin wanita atas jawatannya sebagai Menteri Kebajikan Am dan Yang Dipertua NCWO. Kedudukan jawatan Fatimah Hashim yang bertindan lapis dalam parti politik, kerajaan dan badan bukan kerajaan menggalaskan kebertanggungjawaban kepimpinan wanita ke atas pundaknya dalam pelbagai struktur sekali gus menuntut perubahan.

Kenyataan Fatimah Hashim memegang pelbagai jawatan dilihat dalam struktur institusi dan organisasi Kaum Ibu UMNO (sayap wanita parti politik), Dewan Rakyat (legislatif), Kementerian Kebajikan Am (eksekutif) dan NCWO (gabungan organisasi wanita). Setiap struktur tersebut adalah berlainan hierarki kepimpinan, aktor dan peranannya. Ia mencabar kepimpinan Fatimah Hashim untuk menguruskan matlamat hak wanita dalam pelbagai struktur birokrasi yang tentunya memerlukan pendekatan berbeza. Oleh sebab iltizam Fatimah Hashim untuk memperjuangkan hak wanita, maka agendanya disuarakan di pentas politik dan di belakang tabir. Walaupun demikian, isu wanita yang diperjuangkan Fatimah Hashim telah mengambil tempoh lama untuk berhasil kerana beliau lebih mengutamakan kepentingan politik nasional ke atas kepentingan wanita. Di sebalik semua itu, langkah-langkah strategik untuk menaikkan taraf wanita berjaya diambil Fatimah Hashim. Ia menjadi asas-asas awal kepada kemajuan wanita hari ini.

Pendekatan institusional untuk memperkuat kesatuan wanita pada dekad awal kemerdekaan ialah menerusi penggabungan pelbagai pertubuhan beridentitikan wanita di bawah naungan NCWO. Pembentukan NCWO merupakan salah satu ikhtiar Fatimah Hashim dan rakan-rakan untuk menyatupadukan golongan wanita pelbagai organisasi yang beridentitikan etnik, agama dan kerjaya menerusi sebuah struktur tunggal. Fatimah Hashim menjadi Yang Dipertua NCWO dari tahun 1965. Beliau menerajuinya selama 24 tahun 
hingga persaraannya pada tahun 1989. Di bawah kepimpinan Fatimah Hashim, NCWO mencapai kejayaan sedikit demi sedikit tetapi besar faedahnya terhadap wanita di Malaysia. Pada peringkat awal, NCWO berusaha mewujudkan kesedaran tentang kepentingan peranan wanita yang tidak terlingkar sekitar lingkungan keluarga di rumah, malah menjangkau kehidupan bernegara.

NCWO pimpinan Fatimah Hashim menyuarakan pelbagai isu berkaitan wanita. Antaranya ialah hak wanita yang bersangkut paut hal ehwal agama Islam, gaji sama rata, hal berkaitan prinsip moral, cukai berasingan, undang-undang perkahwinan dan perceraian serta undang-undang berkaitan kes rogol. Di samping itu, di bawah kepimpinan Fatimah Hashim, berlangsungnya peristiwaperistiwa yang menjadi mercu tanda kemajuan wanita Malaysia seperti sambutan Tahun Wanita Antarabangsa 1975, perarakan besar Kemaraan Wanita, pembentukan NACIWID, pembinaan Bangunan NCWO, Perayaan Ulang Tahun NCWO ke-25 dan Memorandum Dasar Wanita (Azizah, 1990).

Keprihatinan Fatimah Hashim ketika menerajui NCWO meliputi isu yang dekat di hati seorang yang bergelar ibu, isteri dan sahabat yang berkongsi perasaan bersama wanita lain. Penganjuran tujuh bengkel sempena Tahun Kanakkanak Antarabangsa 1979 merupakan teras pewartaan Akta Perlindungan Kanakkanak (1990). Resolusi dan usul-usul undang-undang berkaitan diskriminasi wanita disampaikan kepada Kerajaan Malaysia iaitu hasil persidangan dan bengkel sempena Persidangan Wanita Sedunia Ketiga di Nairobi pada tahun 1985. Antaranya ialah keganasan rumah tangga, penjagaan anak-anak, hak harta pusaka, undang-undang buruh, cukai pendapatan dan keselamatan sosial. Selain itu, NCWO berusaha sama menangani masalah VAW yang mendapat asas awalnya melalui aktivisme Joint Action Group against Violence Against Women (JAG-VAW) (Ng, Maznah dan Tan, 2006). Dalam hal ini, pihak NCWO memberikan bantuan kepada mangsa kes rogol dengan kerjasama unit khas Polis Diraja Malaysia (PDRM) yang terdiri daripada pegawai polis wanita dan Kementerian Kesihatan Malaysia yang mengelola alatan pemeriksaan khas untuk mangsa rogol. Sehubungan itu, One Stop Crisis Centres (OSCC) ditempatkan di Hospital Besar Kuala Lumpur (Nik Safiah dan Rokiah, 2003: 134-135).

\section{Kepimpinan Wanita dalam Isu Hak Gaji Sama: Yang Tercabar, Yang Terbukti}

Kajian ini bukanlah kajian deskriptif mendalam yang bertujuan untuk memperincikan setiap isu perjuangan Fatimah Hashim seperti yang telah dinyatakan. Bahagian ini hanya mengupas beberapa isu terpilih yang boleh menonjolkan Fatimah Hashim sebagai pemimpin wanita, khususnya dan masyarakat secara amnya. Satu daripada sumbangan yang signifikan lagi diingati ialah isu tuntutan hak gaji sama untuk wanita. Kejayaan tuntutan gaji sama ialah hasil titik peluh Fatimah Hashim bersama tokoh-tokoh wanita seperjuangan seperti Rasammah Bhupalan dan Helen Tan (Azizah, 1990: 153). Dalam isu ini, 
kedudukan Fatimah Hashim dalam Kaum Ibu UMNO, Ahli Parlimen Padang Terap-Jitra dan Yang Dipertua NCWO meletakkan Fatimah Hashim sebagai jurucakap terpenting untuk isu gaji sama rata dalam pelbagai saluran.

Pada bulan Januari 1962, di Dewan Rakyat, Fatimah Hashim bersama ahli-ahli Parlimen wanita lain membangkitkan soal layanan sama rata terhadap wanita dalam perkhidmatan kerajaan seperti guru-guru wanita (Utusan Melayu, 19 Januari 1962). Fatimah Hashim memberi contoh Singapura yang jauh lebih awal melaksanakan dasar gaji sama. Sehubungan itu, beliau juga menyatakan, "Saya berharap bahawa kerajaan Persekutuan Tanah Melayu tak lama lagi akan menurut inisiatif itu dan saya berjanji akan terus memperjuangkan sehingga tercapai cita-cita persamaan itu" (Warta Negara, 5 Mac 1962). Ia diikuti dengan tindakan Fatimah Hashim menyokong rapat umum anjuran Kesatuan Guru-guru Perempuan Persekutuan Tanah Melayu pimpinan Rasammah Bhupalan yang bertujuan menuntut gaji sama untuk guru-guru wanita. Hasilnya, satu jawatankuasa dan memorandum telah ditubuhkan untuk meneliti tuntutan tersebut (The Straits Times, 27 Mac 1962). Namun, ia bukanlah tugas mudah kerana setelah setahun isu ditimbulkan, ia masih belum diselesaikan di peringkat dasar, walaupun pada masa itu, Fatimah Hashim telah pun menyuarakannya beberapa kali dalam Dewan Rakyat. Sehubungan itu, Fatimah Hashim meletakkan harapan wanita ke atas Tunku Abdul Rahman selaku ketua kerajaan. Fatimah Hashim bertegas bahawa, "Kalau sharat ${ }^{2}$ kelulusan untok mendapat satu ${ }^{2}$ pekerjaan bagi wanita dan lelaki itu sama, maka bererti sama pula-lah layanan yang mesti diberikan" (Berita Harian, 27 Mac 1963). Di samping itu, Fatimah Hashim turut menggunakan Kaum Ibu UMNO sebagai saluran untuk melobi hak gaji sama rata untuk pekerja wanita (Utusan Melayu, 23 Ogos 1963).

Desakan demi desakan tuntutan hak gaji sama rata diartikulasikan oleh pelbagai pertubuhan wanita. Mereka menyerahkan memorandum kepada jabatan kerajaan, tidak terkecuali Majlis Raja-raja Melayu. Akhirnya, ia disetujui secara prinsip oleh kabinet pada tahun 1968. Akan tetapi, ia dilengah-lengahkan atas alasan bahawa kerajaan tidak mampu menanggung kos pelaksanaan. Desakan tuntutan disuarakan menerusi saluran formal dan terbuka seperti perancangan demonstrasi kira-kira 1,000 ahli pertubuhan wanita di Kuala Lumpur. Tuntutan semakin mendesak akibat kelewatan pihak kerajaan menyelesaikan isu ini. Sejak ia mula-mula disuarakan pada tahun 1962, isu ini hanya dipersetujui di peringkat dasar setelah kira-kira enam tahun. Ia tentunya tempoh yang lama. Memetik catatan diari Fatimah Hashim mengenai perjuangan ini, "Saya sadar berjuang untuk mendapatkan hak dan bayaran gaji sama bagi kaum wanita yang kerja dan kelulusannya dengan kaum laki, ada satu perjuangan yang berat, banyak berkehendakkan masa, sabar, tabah hati di-kalangan pejuang ${ }^{2}$ wanita sendiri" (Diari Fatimah Hashim, 1968).

Selanjutnya, bagi menangani isu gaji sama untuk wanita, pendekatan Fatimah Hashim tidak terbatas kepada rundingan secara formal. Malahan, menerusi rundingan secara tidak formal, Fatimah Hashim berunding dengan 
Perdana Menteri Tunku Abdul Rahman secara peribadi. Beliau menegaskan betapa pentingnya tuntutan gaji sama ini dilaksanakan kerana ia menjamin sokongan pengundi wanita untuk Pilihan Raya Umum 1969. Mempertimbangkan sokongan politik itulah Tunku telah berjanji secara peribadi bahawa tuntutan akan segera dilaksanakan sejurus selesainya pilihan raya. Dasar gaji sama bagi wanita dilaksanakan juga akhirnya pada bulan Ogos 1969, setelah berlangsungnya Pilihan Raya Umum 1969 (Azizah, 1990: 153-154).

Tegasnya, Fatimah Hashim memaksimumkan fungsi pelbagai jenis saluran dan pentas untuk memastikan tuntutan gaji sama untuk wanita dan lelaki dilaksanakan oleh pihak kerajaan. Perjuangan beliau dalam isu ini juga memperlihatkan betapa pentingnya jaringan jalinan kerjasama dalam kalangan pemimpin wanita daripada organisasi yang berlainan. Di samping itu, kerjasama pemimpin wanita seperti Fatimah Hashim sendiri, Rasammah Bhupalan dan Aishah Ghani menunjukkan soal tuntutan gaji sama ialah isu wanita Malaysia keseluruhannya. Sesungguhnya, kepimpinan ideal beginilah yang dianjurkan dalam konteks masyarakat tempatan. Seperti ditegaskan oleh Ghazali (1995), kepimpinan ertinya bergerak seiring sejalan berpegangan tangan-bukannya pemimpin berjalan seorang di hadapan tanpa mempedulikan pimpinannya, dan yang dipimpinnya itu pula tidak memahami ke manakah matlamat pemimpin yang mereka ekori.

Selain itu, usaha menuntut gaji sama rata bagi lelaki dan wanita menunjukkan Fatimah Hashim sebagai pemimpin wanita yang berstrategi bagi membawa perubahan. Pertama, Fatimah Hashim memanfaatkan "kepercayaan" yang terbentuk hasil hubungan rapat sesama sahabat seperjuangan, Tunku Abdul Rahman. Sikap saling mempercayai dimanfaatkan Fatimah Hashim untuk membela hak wanita. Beliau mempertaruhkan kepercayaan dan harapan tinggi kepada Tunku Abdul Rahman untuk menyokong hak gaji sama sehingga ia terlaksana. Kedua, bagi memastikan keberhasilan matlamat gaji sama, Fatimah Hashim memberikan peringatan berkenaan peranan golongan wanita sebagai teras kejayaan sesebuah parti politik. Fatimah Hashim mengingatkan bahawa sokongan wanita menerusi peti undi akan dapat dijamin, sekiranya hak gaji sama yang sudah pun berlarutan, tertangguh dan mencetuskan persoalan berjaya dilaksanakan.

Terdapat juga cadangan Fatimah Hashim yang masih lagi belum dilaksanakan hingga ke hari ini. Antaranya ialah penubuhan bank atau syarikat permodalan untuk wanita. Ia menjadi keperluan bagi wanita memajukan diri dalam ekonomi dan politik. Idea penubuhan ini beliau garap daripada lawatan ke Indonesia yang mana di sana terdapat Bank Wanita yang diuruskaan sendiri oleh wanita yang berkelayakan tinggi (Berita Harian, 12 Oktober 1968). Selaku Yang Dipertua NCWO, Fatimah Hashim kerap kali mencadang, sesekali mendesak agar sambutan Hari Wanita pada 25 Ogos diisytiharkan sebagai hari kelepasan am (Berita Harian, 21 Ogos 1972). Namun demikian, tuntutan-tuntutan Fatimah Hashim ini masih belum terlaksana. 
Jelasnya, Fatimah Hashim bukan hanya mengesan jalan untuk muncul sebagai pemimpin menerusi lingkungan sosial, baik keluarga mahupun rakanrakan. Malahan dalam kepimpinannya, Fatimah Hashim memanfaatkan lingkungan sosialnya itu untuk menimba ilmu pengetahuan dan menyumbang kembali kepada pembelaan hak wanita. Atas segala sumbangan Fatimah Hashim ini, beliau dianugerahkan Pingat Emas Tun Fatimah oleh pihak NCWO (1991), Ijazah Doktor Kehormat Pendidikan daripada Universiti Teknologi Malaysia (2000), Anugerah Seri Setia Mahkota oleh Yang di-Pertuan Agong membawa gelaran "Tun" (2003) dan Anugerah Merdeka bagi Kategori Pendidikan dan Komuniti (2009).

\section{KESIMPULAN}

Pemugaran, penerokaan dan penelitian terhadap kepimpinan Fatimah Hashim ternyata memberikan sudut pandang tempatan dalam korpus kajian kepimpinan wanita. Dalam kajian ini, kupasan realiti kepimpinan wanita daripada kaca mata Barat-seperti diulas oleh Eagly dan Carli (2007) terbukti mampu memberi landasan teori dan konsep bagi penjelasan dan pemahaman isu-isu yang dihadapi golongan wanita untuk melonjakkan diri ke mercu kepimpinan. Akan tetapi, apabila kajian ini mengemukakan asas-asas teoretis-empiris pembangunan kepimpinan wanita yang meletakkan titik pusat wacana kepada sarjana tempatan, penjelasannya ternyata lebih memuaskan. Paling tidak, ia sudah pun sedia ada mencakupi konteks kepimpinan Fatimah Hashim.

Dengan mengetengahkan sudut pandang para sarjana tempatan, asas-asas pengupayaan dan pemberdayaan wanita untuk melonjakkan diri ke mercu kepimpinan dapat diusulkan berdasarkan realiti pembangunan kepimpinan wanita yang diharungi Fatimah Hashim. Sehubungan itu, kajian ini menyumbang saran daripada dua sudut. Pertama, sumbangan akademik yang bermaksud memperkaya asas teoretikal dan empirikal dalam pembangunan korpus penyelidikan kepimpinan wanita berkontekskan Malaysia, sekali gus menyarankan pembinaan pengetahuan berasaskan ilmu watan. Kedua, sumbangan terhadap strategi pemberdayaan pembangunan kepimpinan wanita yang menunjukkan perencanaan strategik lagi sistematik bukan sekadar memerlukan usaha bersifat institusional di peringkat kerajaan, bahkan perlu didorong oleh peranan lingkungan kekeluargaan. Kedua-dua sumbangan tersebut terpancar menerusi realiti kepimpinan wanita Fatimah Hashim yang bukan sahaja tersimpul erat dalam wacana teoretis tetapi juga tersimpan elok dalam kajian bersifat historis. Oleh yang demikian, kajian ini mengusulkan pembinaan ilmu watan kepimpinan wanita dipergiatkan agar penteorian kajian wanita bernuansa tempatan dapat diperkaya, lantas diperteguhkan. 


\section{PENGHARGAAN}

Artikel ini ialah hasil kajian kumpulan penyelidikan PKW-2013-015 Siri Srikandi Negara menerusi dana Kursi Kepimpinan Wanita di bawah Kementerian Pembangunan Wanita, Keluarga dan Masyarakat (KPWKM).

\section{RUJUKAN}

Andek Masnah Andek Kelawa. 1999. Kepimpinan wanita dalam Islam: Kedudukannya dalam syariah. Bangi: Penerbit Universiti Kebangsaan Malaysia.

Azizah Mokhzani. 1990. Fatimah: Srikandi sumber inspirasi. Kuala Lumpur: Majlis Kebangsaan Pertubuhan-pertubuhan Wanita Malaysia.

Berita Harian. 21 Ogos 1972. 12 Oktober 1968. $27 \mathrm{Mac} 1963$.

Dancz, V. H. 1987. Women and party politics in Peninsular Malaysia. Singapore: Oxford University Press.

Diari Fatimah Hashim. 1968.

Eagly, A. H. and Carli, L. L. 2007. Through the labyrinth: The truth about how women become leaders. Massachusetts: Harvard Business School Press.

Ghazali Shafie. 1995. Rumpun Melayu dan bangsa Malaysia menjelang tahun 2020. Bangi: Penerbit Universiti Kebangsaan Malaysia.

Hoyt, C. L. 2007. Women and leadership. In Leadership: Theory and practice, ed. P. G. Northouse, 265-299. London: Sage.

Ibrahim Ahmad Aliyu. 2010. Protection of women's rights under the shari'ah. Petaling Jaya: Dakwah Corner Bookstore.

Jamilah Ariffin. 1992. Women and development in Malaysia. Petaling Jaya: Pelanduk Publications.

Kamilia Ibrahim. 1998. The involvement of Malay Women in politics and the need for a paradigm shift. In Malaysian women in the wake of change, ed. Sharifah Zaleha Syed Hassan, 105-110. Kuala Lumpur: Gender Studies Programme, University of Malaya.

Mahani Musa. 2010. Wanita Melayu, kesedaran pendidikan dan pembentukan masyarakat Malaysia moden. Malaysia Dari Segi Sejarah 38: 1-24.

Mahfudzah Haji Mustafa. 2000. Kepimpinan politik: Pengalaman Ibu Zain. In Antara kebaya dan gaun: Pengalaman dan citra wanita Melayu zaman pra-merdeka, eds. Fuziah Kartini Hassan Basri, Zaharah Hassan and Bahiyah Abdul Hamid, 199-220. Bangi: Jabatan Komunikasi, Universiti Kebangsaan Malaysia. 
Manderson, L. 1987. Malay women in politics reconsidered. Jurnal Antropologi \& Sosiologi 15: 3-16.

1980. Women, politics and change: The Kaum Ibu UMNO Malaysia 1945-1972. Petaling Jaya: Oxford University Press.

. 1978. The development and direction of female education in Peninsular Malaysia. Journal of the Malaysian Branch of Royal Asiatic Society 51(2): 100-122.

Muhammad Rahimi Hasan. 2014. Gerakan nasionalisme (1945-1957) sebagai wadah emansipasi wanita Melayu. Master diss., School of History, Politics and Strategic Studies, National University of Malaysia.

Ng, C. C. S., Maznah Mohamad and B. H. Tan. 2006. Feminism and the women's movement in Malaysia: An unsung (r)evolution. Oxon: Routledge.

Nik Safiah Karim. 1990. Wanita Malaysia: Harapan dan cabaran. Kuala Lumpur: K Publishing \& Distributors.

—. 1985. Dekad wanita 1975-85: Satu pengenalan ringkas. Kuala Lumpur: Jabatan Percetakan Negara.

Nik Safiah Karim and Rokiah Talib. 2003. Tan Sri Fatimah: Potret seorang pemimpin. Subang Jaya: Pelanduk Publications.

Northouse, P. G. 2007. Leadership: Theory and practice. California: Sage.

PERTIWI. 2004. Biografi tokoh wanita Malaysia. Petaling Jaya: PERTIWI. . 1983. Biografi wanita Malaysia. Kuala Lumpur: PERTIWI.

Ramlah Adam. 1993. Kepimpinan Pergerakan Wanita UMNO. In Pergerakan Wanita UMNO sepanjang lima dekad, eds. Rusiah R. Abdullah and Nor Anida Umam, 23-27. Kuala Lumpur: Kembangan Kristal.

Rashila Ramli. 1995. Gender, rural development and Islam in Malaysia: Farmers, wives and $(\mathrm{m})$ others at Jengka Felda schemes. PhD diss., Northern Arizona University.

Rashila Ramli and Saliha Hassan. 1998. Trends and forms of women's participation in politics. In Malaysian women in the wake of change, ed. Sharifah Zaleha Syed Hassan, 88-104. Kuala Lumpur: Gender Studies Programme, University of Malaya.

Rokiah Talib. 2007. Peranan wanita untuk memulihkan integriti politik. In Integriti politik di Malaysia: Ke arah kefahaman yang lebih sempurna, eds. Anis Yusal Yusoff, Mohd Rais Ramli and Zubayry Abady Sofian, 162-188. Kuala Lumpur: Institut Integriti Malaysia.

Saliha Hassan. 1994. Formal and non-formal education system and political development of women. In Malaysian women creating their political awareness, eds. R. Haas and Rahmah Hashim, 95-101. Kuala Lumpur: Asian Institute for Development Communication.

Syed Farid Alatas. 1994. The status of feminist theory in Malaysia. Special issue, Feminism: Malaysian critique and experience. Kajian Malaysia (Journal of Malaysian Studies) 12(1-2): 25-46. 
Tan, J. S. A. 1981. The education on Malay girls: A brief history. Malaysia in History 15: 117-123.

The Noble Qur'an. https://quran.com/.

The Straits Times. 27 Mac 1962.

Ting, H. M. H. 2007. Khadijah Sidek and Fatimah Hashim: Two contrasting models of (Malay) feminist struggle? In Malaysia public policy and marginalised groups, ed. K. L. Phua, 115-142. Kajang. Persatuan Sains Sosial Malaysia.

Utusan Melayu. 23 Ogos 1963. . 19 Januari 1962. . 9 Januari 1961.

Warta Negara. 5 Mac 1962.

Wazir Jahan Karim. 1992. Women and culture: Between Malay adat and Islam. Colorado: Westview Press.

. 1981. The development of Malay female leadership in Peninsular Malaysia. Pulau Pinang: KANITA.

Zaharah Hassan. 2000. Kepimpinan Khatijah Sidek: Antara realiti dan persepsi. In Antara kebaya dan gaun: Pengalaman dan citra wanita Melayu zaman pra-merdeka, eds. Fuziah Kartini Hassan Basri, Zaharah Hassan dan Bahiyah Abdul Hamid, 183-198. Bangi: Jabatan Komunikasi, Universiti Kebangsaan Malaysia. 